\title{
Determination of heavy metals content in tea leaves and products of their processing by method of inversion voltammetry
}

\author{
S.I. Maharramova* \\ Azerbaijan State University of Economics, Baku, Azerbaijan
}

\begin{abstract}
This paper shows that some heavy metals generate free radicals that can lead to oxidative stress and cause other cellular damage, a carcinogenic effect, affecting a number of proteins. As a result of the measurement, it was found that in green tea leaves the content of concentrations of $\mathrm{Zn}, \mathrm{Cd}, \mathrm{Pb}, \mathrm{Cu}$ is $2.90 \pm 1.10 ; 0,029 \pm 0,029 ; 0.11 \pm 0,040$ and $3.10 \pm 1.10 \mathrm{mg} / \mathrm{kg}$, respectively. Their lowest content was found in drinks from black baikha tea $-0.039 ; 0,036 \pm 0,014 ; 0,044 \pm 0,016$ and 0,054 $\pm 0,020 \mathrm{mg} / \mathrm{kg}$, respectively. Content of concentrations of $\mathrm{Zn}, \mathrm{Cd}, \mathrm{Pb}, \mathrm{Cu}$ in tea extract with weight fraction of dry substances of $30.0 \%$ is $7.90-9.59$ times more than in beverages from black baikha tea. The mass concentration of toxic metals $\mathrm{Cd}, \mathrm{Pb}$ in all analysed samples of tea leaves and tea drinks is less than their permissible levels specified in regulatory documents in force in the Republic of Azerbaijan.
\end{abstract}

\section{Introduction}

Recently, food safety has become one of the most important hygienic problems, which has become more relevant in the space of the Commonwealth of Independent States after the collapse of the USSR. This is due to the fact that more and more food raw materials and food products (sometimes of dubious origin and quality) are coming to our consumer market from abroad, changing production technologies, storage and sales conditions. All new chemicals are added to food, the quantity of which is increasing. Contaminated food and raw materials are more at risk due to adverse environmental conditions.

According to sanitary and epidemiological norms and rules, the Ministry of Health of the Republic of Azerbaijan defines food safety criteria mainly according to the following elements: mercury, cadmium, lead, arsenic.

These heavy metals accumulate in the human body and plants as a result of various processes that cause negative effects. Heavy metals such as $\mathrm{Zn}, \mathrm{Cd}, \mathrm{Pb}, \mathrm{Cu}$ are transported and separated into cells and body tissues by binding to proteins, nucleic acids destroy these macromolecules and disrupt their cellular functions [1-6]. Toxicity of $\mathrm{Zn}, \mathrm{Cd}, \mathrm{Pb}, \mathrm{Cu}$ can have several consequences for the human body, can affect the function of the central nervous system, damage blood components and can damage the lungs, liver, kidneys and other vital organs, can cause a number of diseases [1,5-7].

\footnotetext{
${ }^{*}$ Corresponding author: maqerramovasevinc75@mail.ru
} 
One of the most popular and daily drinks consumed around the world, including in Azerbaijan, is tea [8]. Tea plant - Camellia sinensis [Camellia sinensis O. Kunze] or Camellia assamica [Caellia sinensis. Assamica (Mast.) Kitamura] - shoots, flashes, leaves and fibers are used as raw materials for the production of various tea products. Undoubtedly, Camellia sinensis is the most common and most used plant source in the world for tea.

At the same time, many types of tea drinks packed in glass containers, for example, flavored, clean, dairy and other tea drinks and instant teas, are sold in consumer markets in various countries, including Azerbaijan [8].

Dry tea extract or instant tea powder is a product with high biological value according to unique chemical composition, excellent organoleptic index and favorable physiological effect of organism [9].

Tea extracts can be used in production of alcoholic, non-alcoholic and low-alcoholic beverages, bakery, confectionery, etc. in amount of $5-15 \%$ of initial raw materials. This is based on organoleptic indicators and an increase in the biological value of the finished product, partly its cheap cost and accessibility for most groups of the population. The conducted studies [10] allow to obtain a natural and functional extract of tea from black and green tea. Use of these extracts promotes functional administration of soft and low-calorie beverages, food concentrates, bakery and confectionery products, instant products and their use for therapeutic and dietary purposes.

Studies and forecasts show that by strengthening state support for the development of tea growing from traditional industries in the Lankaran economic region and the effective use of available resources for the development of tea farming in the region by 2030 , it is possible to increase the area of tea plantations in the republic to 5.0 thousand hectares, and the production of green tea leaf - to 14.5-15.0 thousand tons [8].

However, research on the content of heavy toxic metals such as $\mathrm{Zn}, \mathrm{Cd}, \mathrm{Pb}, \mathrm{Cu}$ in fresh tea leaves grown in the Lankaran-Astara region of Azerbaijan and their products is lacking.

The purpose of this work is to study the content of $\mathrm{Zn}, \mathrm{Cd}, \mathrm{Pb}, \mathrm{Cu}$ in fresh tea leaves and their products.

\section{Materials and methods of research}

The subjects of the study were green tea sheets grown, zoned and introduced in the farms of the Republic of Azerbaijan, received for processing in the period May-September months 2018-2019, as well as a tea drink from black baikha tea and tea extract with a mass proportion of dry substances of $30.0 \%$.

To determine the content of heavy metals in tea leaves and products of their processing, we used the method of measurements of mass concentration of zinc, cadmium, lead and copper in tea leaves and products of their processing by method of inversion voltammetry after preliminary preparation of samples by "wet" mineralization [11,12]. The range of measurements, values of accuracy, correctness, repeatability and reproducibility of the technique with a confidence probability $\mathrm{P}=0.95$.

The work was carried out in the educational and research laboratory of the Department of Engineering and Applied Sciences of Azerbaijan State Economic University in collaboration with the laboratory "Ecology and Food Safety" of the Department of Technology and Technical Disciplines of Lankaran State University.

\section{Discussion of results}

The results of the analyses of toxic metals $(\mathrm{Zn}, \mathrm{Cd}, \mathrm{Pb}, \mathrm{Cu})$ in tea leaves and their products for the years 2018-2019 are shown in the table and in Figures 1 and 2. 
As can be seen from the table, relatively high concentrations of $\mathrm{Zn}, \mathrm{Cd}, \mathrm{Pb}, \mathrm{Cu}$ were found in green tea leaves. The lowest content of $\mathrm{Zn}, \mathrm{Cd}, \mathrm{Pb}, \mathrm{Cu}$ is found in black baikha tea drinks. Content of concentrations of $\mathrm{Zn}, \mathrm{Cd}, \mathrm{Pb}, \mathrm{Cu}$ in tea extract with weight fraction of dry substances of $30.0 \%$ is $7.90-9.59$ times more than in beverages from black baikha tea.

Table 1. Average data on mass concentrations of toxic metals in tea sheets and their products

\begin{tabular}{|c|c|c|c|c|}
\hline \multirow{2}{*}{$\begin{array}{l}\text { Description of raw } \\
\text { materials and products }\end{array}$} & \multicolumn{4}{|c|}{ Mass concentration content, $\mathrm{mg} / \mathrm{kg}$} \\
\hline & $Z n$ & $C d$ & $\mathrm{~Pb}$ & $\mathrm{Cu}$ \\
\hline Green tea sheets & $2,90 \pm 1,10$ & $0,029 \pm 0,029$ & $0,11 \pm 0,040$ & $3,10 \pm 1,10$ \\
\hline $\begin{array}{l}\text { Drink from black baikha } \\
\text { tea }\end{array}$ & 0,039 & $0,036 \pm 0,014$ & $0,044 \pm 0,016$ & $0,054 \pm 0,020$ \\
\hline Tea extract, $30 \%$ & $0,312 \pm 0,12$ & $0,27 \pm 0,17$ & $0,368 \pm 0,14$ & $0,518 \pm 0,19$ \\
\hline
\end{tabular}

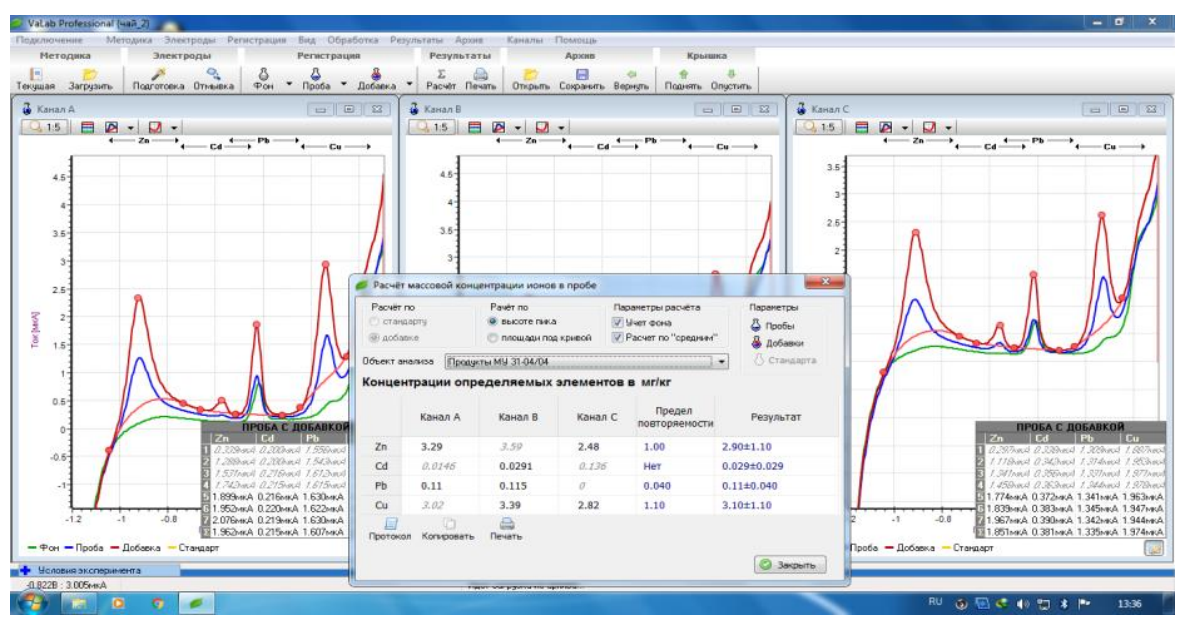

Fig. 1. Voltamperogram content of mass concentrations of toxic metals $(\mathrm{Zn}, \mathrm{Cd}, \mathrm{Pb}, \mathrm{Cu})$ in fresh green tea leaves

The difference in the content of toxic metal concentrations in tea drinks and extracts is due to the use of technological techniques. So, when extracting tea leaves, metals migrate from the raw material to the liquid medium, and at its concentration with an initial mass fraction of dry substances of 5.0-6.0\% to the extract with a mass fraction of dry substances up to $30.0 \%$, at the same time the content of toxic metals increases, as indicated above by 7.90- 9.59 times. The results obtained are consistent with data of other authors [13]. 


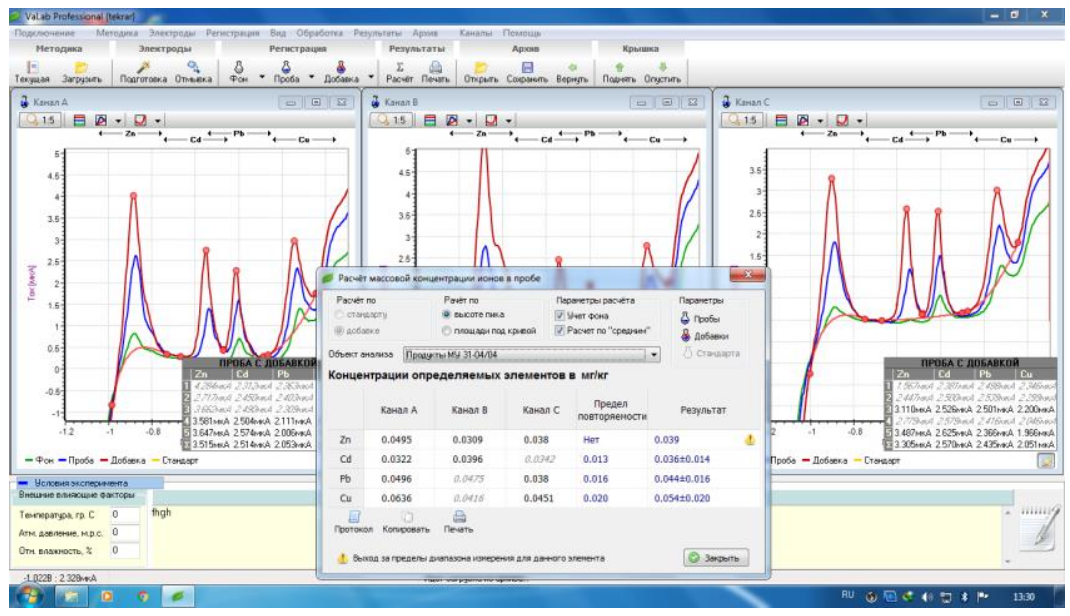

Fig. 2. Voltamperogram content of mass concentrations of toxic metals $(\mathrm{Zn}, \mathrm{Cd}, \mathrm{Pb}, \mathrm{Cu})$ in drinks from black baikha tea

The results of the analyses in Table 1 and Figures 2 show that the total concentrations of all tested toxic metals $(\mathrm{Zn}, \mathrm{Cd}, \mathrm{Pb}, \mathrm{Cu})$ in tea leaves are slightly higher than in tea drinks and extracts. The voltamperogram content of the mass concentrations of toxic metals in tea leaves and beverages from black baikha tea shown in Figures 1 and 2 also shows the reliability of the obtained results of the measurements of the mass concentration of each element in the analysed sample and the acceptability of this procedure.

According to the Sanitary Code in force in the Republic of Azerbaijan

epidemiological rules and norms "Hygienic requirements for food safety and nutritional value" [14], permissible level of $C d, P b$ in tea products, not more than $1.0 \mathrm{mg} / \mathrm{kg}$ and 10.0 $\mathrm{mg} / \mathrm{kg}$, respectively.

As the results of our studies show, content of mass concentrations of toxic metals $\mathrm{Cd}, \mathrm{Pb}$ in all analysed samples of tea leaves and their products is less than their permissible levels specified in [14]. The content of mass concentrations of $\mathrm{Zn}, \mathrm{Cu}$ in tea leaves and their products is not regulated by this document.

\section{Conclusion}

Partial analysis of existing literature and patent information sources shows that some heavy metals generate free radicals that can lead to oxidative stress and cause other cellular damage, a carcinogenic effect, affecting a number of proteins.

As a result of the measurement, it was found that in green tea leaves the content of concentrations of $\mathrm{Zn}, \mathrm{Cd}, \mathrm{Pb}, \mathrm{Cu}$ is $2.90 \pm 1.10 ; 0,029 \pm 0,029 ; 0.11 \pm 0,040$ and $3.10 \pm 1.10$ $\mathrm{mg} / \mathrm{kg}$, respectively. Their lowest content was found in drinks from black baikha tea - 0.039 ; $0,036 \pm 0,014 ; 0,044 \pm 0,016$ and $0,054 \pm 0,020 \mathrm{mg} / \mathrm{kg}$, respectively. Content of concentrations of $\mathrm{Zn}, \mathrm{Cd}, \mathrm{Pb}, \mathrm{Cu}$ in tea extract with weight fraction of dry substances of $30.0 \%$ is $7.90-9.59$ times more than in beverages from black baikha tea. The mass concentration of toxic metals $\mathrm{Cd}, \mathrm{Pb}$ in all analysed samples of tea leaves and tea drinks is less than their permissible levels specified in regulatory documents in force in the Republic of Azerbaijan.

The method of inversion voltammetry to determine the mass concentration of heavy metals does not require specialized expensive equipment, qualified personnel and long-term sample preparation. Therefore, given the simplicity and accessibility, we consider it appropriate to use this method to determine the mass concentration of heavy metals. 


\section{References}

1. M.A. Maharramov, S.I. Maharramova, I.G. Kazimova, Safety of raw materials and food products, 270 (2019)

2. S.A. Khotimchenko, $X$ Vseros. Congress of hygienists and sanitary doctors, 1, 1054 (2007)

3. A. M. Vasilovsky, XI Vseros. Congress of hygienists and sanitary doctors, 3, 57 (2012)

4. O.A. Frolova, Preventive Medicine, 3, 34 (2012)

5. S.P. Dolan, J. Agric. Food Chem, 51(5), 1307 (2003)

6. J. Monisha, T. Tenzin, A. Naresh, B.M. Blessy, N.B. Krishnamurthy, Interdisciplinary Toxicology, 7(2), 60 (2014)

7. L. Jarup, British Medical Bulletin, 68(1), 167 (2003)

8. M.A. Maharramov, M.M. Jahangirov, S.I. Maharramova, Tea- Chemistry and Pharmacology, 129 (2020)

9. L.D. Ververny, Beer and Drinks, 2, 42 (2008)

10. M.M. Jahangirov, World Science RS Global, 1(12/52), 4 (2019)

11. M.A. Maharramov, A.A. Jalalov, S.I. Maharramova and M.M. Jahangirov, Advances in Clinical Toxicology, 6(1), 1 (2021)

12. MU 08-47/242. Procedure for measurement of mass concentration of zinc, cadmium, lead and copper by inversion voltammetry using TA type analyzers, 16 (2009)

13. O.V. Benderskaya, V.V. Shutyuk, A.S. Bessarab, III International Scientific and Practical Conference, 481 (2017)

14. Order of the Ministry of Health of the Azerbaijan Republic of 30.04.2010, 25 (2010) 